\title{
PERFORMING ARTS
}

J 0 U R N A L

\section{Bonnie Marranca and Gautam Dasgupta, Editors}

Under continuous editorship since its founding in 1976, Performing Arts Journal has been an influential voice in the arts for twenty years. Now in a new format and design, PAJ offers extended coverage of the visual arts (such as video, installations, photography, and multimedia performance), in addition to reviews of new works in theatre, dance, film, and opera. Issues include artists writings, critical and historical interviews, performance texts and plays, reports on performance abroad, and book reviews.

A new special section entitled "Art \& Performance Notes" features artists' documentation and critical reviews of current arts events, especially performances and museum/gallery shows.

Published three times a year in January, May, and September for PAJ Publications.

Prepayment is required. Annual subscription: $\$ 22.00$, individuals; $\$ 46.00$, institutions. Foreign postage: $\$ 5.50$, Canada \& Mexico; $\$ 7.50$, outside North America. Payment must be drawn on a U.S. bank in U.S. dollars or made by international money order. MD residents add $5 \%$ sales tax. For orders shipped to Canada add 7\% GST (\#124004946RT)

To order your subscription using MasterCard or Visa, call toll-free 1-800-548-1784, or send orders to this E-mail address: jlorder@jhunix.hcf.jhu.edu Or send check or money order drawn on U.S. bank in U.S. dollars, payable to:

The Johns Hopkins University Press, Journals Publishing Division, P.O. Box 19966, Baltimore, MD 21211.0966.

1) Published by The Johns Hopkins University Press

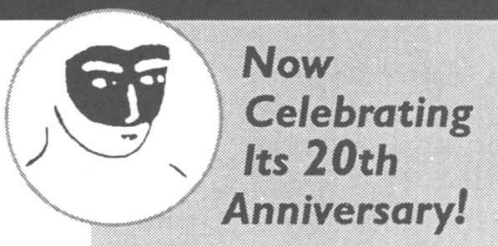

Since $1976, P A J$ has published or interviewed such important 20th-century artists and essayists as:

- Umberto Eco

- Maria Irene Fornes

- Sam Shepard

- Edward Said

- Rainer W. Fassbinder

- Susan Sontag

- Philip Glass

- Carolee Schneemann

- Laurie Anderson

- John Cage

- Robert Jay Lifton

- Eugene lonesco

- Tadashi Suzuki

- Anna Halprin

- Mac Wellman

- Tadeusz Kantor

- Anna Deavere Smith

- and many others. 


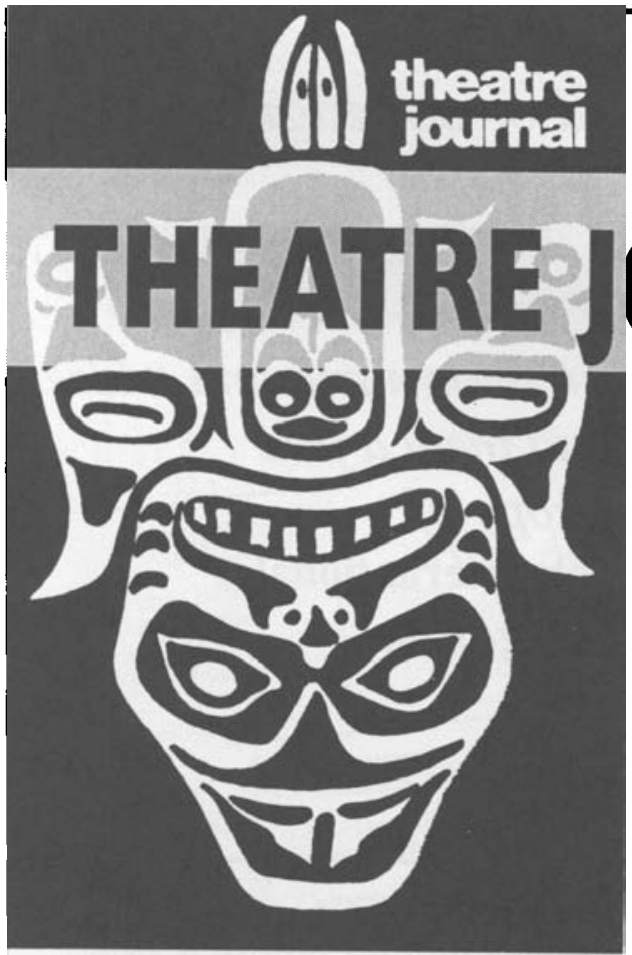

OURNAL

John Rouse, Editor Loren Kruger, Co-editor

For over four decades, Theatre joumal's broad array of scholarly articles and reviews have eamed it an international reputation as one of the most authoritative and useful publications of theatre studies available today. Drawing contributions from noted practitioners and scholars, Theatre joumal features social and historical studies, production reviews, and theoretical inquiries that analyze dramatic texts and production. Published four

times a year in March, May, October, and December in cooperation with the Association for Theatre in Higher Education.

October 1996 (Volume 48, Number 3) includes: "Raising the Roof': Authors, Spectators, and Artisans in the Grand Federal Procession of 1788 - The Sioux War Panorama and American Mythic History - Street Fairs: Social Space, Social Performance - Immigrant Popular Culture as a Contested Sphere: Yiddish Music Halls, the Yiddish Press, and the Processes of Americanization, 1900-1910 - Civic Play-Housekeeping: Gender. Theatre, and American Reform - Performance Reviews - Book Reviews

Prepayment is required. Annual subscriptions: $\$ 28.00$, individuals; $\$ 63.00$, institutions. Foreign postage: $\$ 4.00$, Canada \& Mexico; $\$ 10.00$, outside North America. Single-issue prices: $\$ 8.00$. individuals; $\$ 17.00$, institutions. Payment must be drawn on a U.S. bank in U.S. dollars or made by international money order. MD residents add $5 \%$ sales tax. For orders shipped to Canada add 7\% GST (\#|24004946RT).

Send orders to:

The Johns Hopkins University Press, P.O. Box 19966, Baltimore, MD 2121 I-0966. To place an order using Visa or MasterCard, call toll-free 1-800-548-1784, FAX us at (410) 516-6968, or send Visa/MasterCard orders to this E-mail address: jlorder@jhunix.hcf.jhu.edu

Visit our WEBsite at: http://www.press.jhu.edu/journals/theatre journal/ 
Introduce a friend or colleague to

\section{THEATRE RESEARCH INTERNATIONAL}

Photocopy this page, fill in their name and address and we will send them a free sample copy of

Theatre Research International without obligation.

I would like you to send the person named below a free sample copy of Theatre Research International without obligation.

Name

Address

Postcode

Country

Return to the

Journals Marketing Department (FF), Oxford University

Press, Walton Street, Oxford OX2 6DP, UK

or Fax (0) 1865267782

and we'll do the rest! 


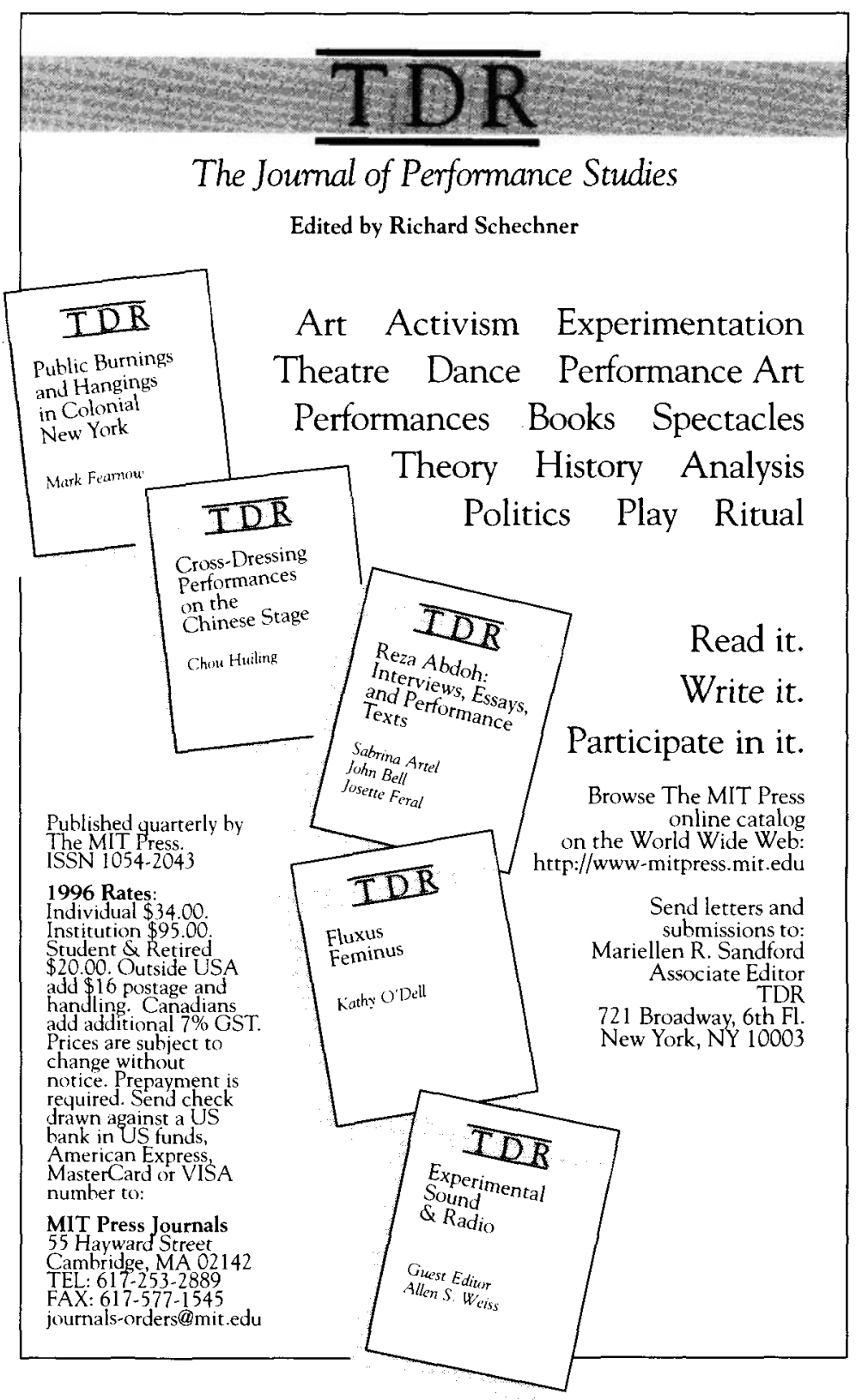




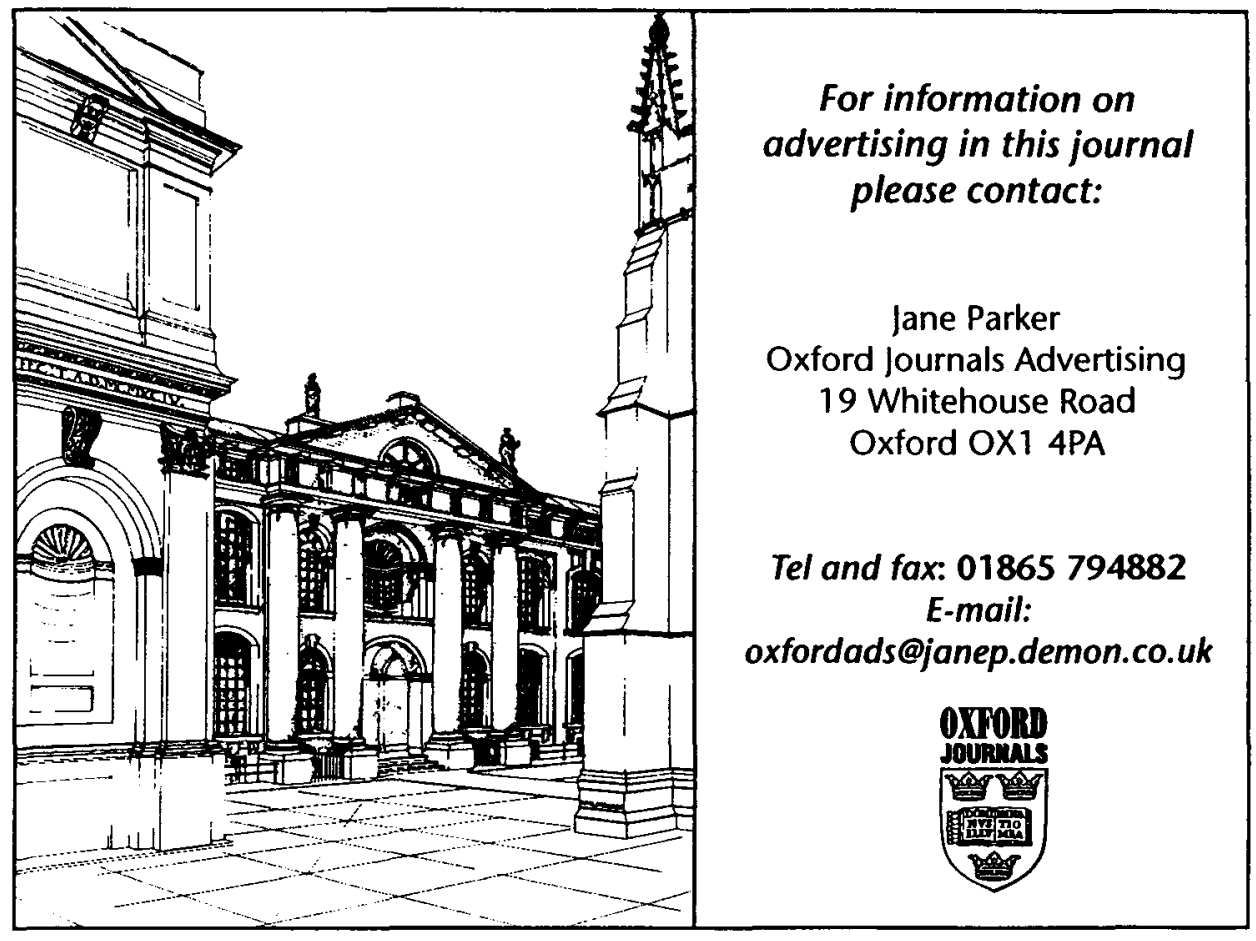




\title{
THE INTERNATIONAL FEDERATION FOR THEATRE RESEARCH \\ LA FEDERATION INTERNATIONALE POUR LA RECHERCHE THEATRALE
}

\author{
Founded in 1957 with the following aims:
}

To promote in all countries international liaison between organizations and individuals devoted to theatre research.

To organize international conferences and symposia.

To obtain facilities in libraries, museums, etc., for theatrical workers of all countries.

To submit to the authorities of all countries the desirability of creating courses, institutes and chairs of theatre research.

The IFTR has the following sections:

THE VENICE INTERNATIONAL INSTITUTE FOR THEATRE RESEARCH THE UNIVERSITIES COMMISSION, specially charged with research within universities and the promotion of teaching of Theatre Studies throughout the world.

All members receive the journal Theatre Research International published by the Oxford University Press in association with the IFTR and a news bulletin twice a year.

INSTITUTIONAL MEMBERS: INDIVIDUAL MEMBERS:

\section{MEMBERSHIP AND ANNUAL SUBSCRIPTION}

Bodies whose sole function is theatre research, $225 \mathrm{Sw}$. Fr.

Individuals who wish to participate in the work of the IFTR and to support it, $80 \mathrm{Sw}$. Fr.

Enquiries and application for membership should be addressed to

Membership Secretariat, IFTR/FIRT

9/118 Avenue Road, London, W3 8QG, Great Britain.

The International Federation for Theatre Research

La Fédération Internationale pour la Recherche Théâtrale

announces the

\section{Second Annual New Scholar's Prize}

for the best essay by a new scholar, who must be under 35 years of age or who will not have completed his/her Ph.D. prior to May 1997, on the topic of the FIRT/IFTR Annual Conference to be held in Cholula, Puebla, Mexico, in June 1997:

Theatres and Cultures in the World

Theories and Practices in Today's Theatre

The essay, not to exceed 5000 words, should be submitted in hard copy and on disk, and should focus on the relationship between theatre and cultures in the world, theories and practices in today's theatre; or the connection between them. Languages: English or French.

The New Scholar's Prize consists of airfare, fees and accommodation for the IFTR/FIRT Conference in Cholula, Puebla, June 23-28, 1997, and a year's membership in the organization. There will be an opportunity to publish the essay in Theatre Research International.

Deadline for receipt of essays: 1 March 1997

Send submissions to:

Janelle Reinelt

Chair of Dramatic Art and Dance / Dramatic Art Department

University of Calfornia / Davis, CA 95616-8577, USA

Tel: (916) 752-0891 or (916) 752-0888

E-mail: jgreinelt @ ucdavis.edu 